Article

\title{
The Analysis of Japan's Energy and Climate Policy from the Aspect of Anticipatory Governance
}

\section{Hiroshi Ohta}

School of International Liberal Studies, Faculty of International Research and Education, Waseda Campus, Waseda University, Tokyo 169-0051, Japan; h-ohta@waseda.jp

Received: 27 August 2020; Accepted: 28 September 2020; Published: 2 October 2020

\begin{abstract}
This study is a preliminary and experimental one to analyze Japan's energy transitions to mitigate climate change from anticipatory governance aspects. Japan's energy policy principles have been energy security, environmental considerations, economic efficiency, and safety (3E $+S$ ). According to the energy agency, the long-term energy outlook is also drawn up by "ambitious multiple track scenarios" and "multilayered and diversified flexible energy supply-demand structure." This approach resonates with the aspects of anticipatory governance. It promotes the idea of preparing for multiple future scenarios, including the unthinkable worst case future scenario such as a nuclear accident (foresight), the interactions between the policymakers and the public (engagement), and the reflexive processes of policy innovations with a normative decision for the selection of energy mix (integration). However, this study finds that Japan's energy policy lacks the aspects of anticipatory governance. It sticks to fixed energy policy institutionalized in the 1970s to promote nuclear energy and coal as oil alternatives. It rarely has interactions between the policymakers and the public and thus lacks a societal (normative) decision about a future energy path to energy transitions to mitigate climate change. Instead, Japan's energy policy has not necessarily met its declared policy objective of $3 \mathrm{E}+\mathrm{S}$ since the unprecedented Fukushima nuclear accidents occurred and cannot uphold an ambitious target for $\mathrm{CO}_{2}$ emissions reduction.
\end{abstract}

Keywords: anticipatory governance; foresight; engagement; integration; renewables; Fukushima; energy policy; energy transition; climate change policy

\section{Introduction}

We face various complex governance problems and "wicked" problems. Energy transitions are complex governance problems in which multilayers of different actors with conflicting interests and goals involve different and contesting values that exist on policy goals such as energy security and sustainability, a range of uncertainties in knowledge, and future technological developments. Similarly, we need to deal with the so-called "wicked problems" such as climate change, regional and global order, and cybersecurity. They are hard to pin down since we are not able to grasp them in their entirety, even what are precisely the problems, let alone to find out their solutions.

No country other than Japan urgently needs energy transitions from nuclear and fossil energy to renewable energy sources. The Great East Japan Earthquake and Tsunami on 11 March 2011 triggered the unprecedented three nuclear reactors' meltdown and melt-through at the Fukushima Daiichi (No. 1) nuclear power complex. Right after this accident, the government, led by the Democratic Party of Japan (DPJ), briefly upheld the policy of the nuclear phaseout by 2030, but the current government, led by the Liberal Democratic Party (LDP), reversed this policy and still seeks the utilization of nuclear energy in the future. The Cabinet approved the Fifth Basic Energy Plan (or the Energy Strategy) on 3 July 2018 in which nuclear power, from the aspect of energy security and decarbonization, will remain a key energy source accounting for $20-22 \%$ of the country's electricity generation up to 2030 [1]. While renewable 
energy targets are $22-24 \%$, slightly larger than nuclear, fossil fuels will occupy more than $50 \%$ of electricity generation. Japan's nationally determined contributions (NDCs) under the Paris climate agreement are much less ambitious than the EU's target of 40\% reductions below 1990 levels by 2030 . Japan pledged 26\% reductions below 2013 (or equivalent to 18\% reductions below 1990 levels) by 2030 .

Why has Japan not chosen the path to the denuclearization policy or gradual phaseout of nuclear power plants despite the severe accident? Instead of aggressively pursuing the policy of decarbonizing its economy, why does Japan continuously depend on Middle Eastern oil and gas even though energy security concern is one of the tenets of Japan's energy policy? Why has Japan not steered its energy policy toward energy transitions from nuclear and fossil fuels to renewable energy? What are the significant barriers to this energy path, and how can Japan overcome them to seek a sustainable energy policy while addressing climate change mitigation?

This article analyzes Japan's historical and current energy and climate policy through the aspects of anticipatory governance, aiming at identifying what Japan's energy-climate policy-making processes lack and how to improve them. The focal point of this research is the energy policy of the Ministry of Economy, Trade and Industry (METI). Since the Japanese energy policy has failed to meet its policy objectives of safety, energy security, environmental considerations including the substantial emission reductions of greenhouse gases, and economic efficiency, it needs an alternative way to transition toward sustainable energy. For its purpose, this article examines how useful the approach of anticipatory governance is to avoid the recurrence of a major catastrophe such as the Fukushima nuclear accident.

There are several excellent studies on Japanese energy and climate change policy. Samuels' comparative and historical analysis of Japan's energy policy is the seminal study [2]. Moe persuasively argues that vested interests hinder energy transitions to renewables in Japan [3,4]. Kameyama thoroughly documents Japan's climate change policy [5], while Watanabe presents a well-structured comparative analysis of climate change policy in Germany and Japan [6]. All of these studies are robust empirical studies, either historical, analytical, descriptive, or comparative. Highly appreciating their studies, this article attempts to incorporate a normative aspect imperative to deal with energy transitions and climate change. We could not confidently predict an earthquake and the outbreak of pandemics or assess climate change consequences. We can prepare for the worst-case scenario by imagining the unimaginable to reduce the damages as much as possible, making a normative decision about what kind of future we want to have. In this sense, the author finds the concept of anticipatory governance significant to analyze Japan's energy transitions to mitigate climate change.

This chapter employs the process-tracing method [7], giving a detailed account of the critical decision-making processes and describing the core elements of energy policy closely related to climate change policy.

\section{Anticipatory Governance and Complex Governance Problems}

\subsection{Various Approaches to Complex Governance Problems}

There are numerous approaches to how to deal with complex governance problems. Collaborative governance or multi-actor governance addresses cooperation and negotiation between multiple interdependent actors in complex governance problems [8,9]. According to network governance, a policy network consisting of policymakers, concerned interests, and other stakeholders is defined as a body of stable relations between mutually dependent actors. Network governance's core concepts are to analyze networks include rules, interaction patterns, and (shared) perceptions that contribute to achieving collective action $[10,11]$. We also have to seek multi-level governance in dealing with contemporary problems in a seamless world [12,13]. Adaptive governance has developed as a managerial approach to socio-ecological systems. Folke and his colleagues study governance experiences concerning complex adaptive ecosystems and particularly "during periods when change is abrupt, disorganizing, or turbulent" [14] (p. 444). Essential elements of adaptive governance include 
social capital (or networks), social memory, "learning to live with change and uncertainty, combining different types of knowledge for learning, creating the opportunity for self-organization toward social-ecological resilience, and nurturing sources of resilience for renewal and reorganization" [14] (p. 452).

Transition management and the politics of transition management also suggest how to deal with complex governance problems. Transition management claims that innovative technological developments bring the revolutionary changes in the existing social, technological regimes and eventually transform the macroeconomy, social customs, and political situations [15]. Kemp and his colleagues maintain that "transition management is a co-evolutionary steering concept that involves a cyclical process of notions, ideas, instruments and mechanisms that co-evolve: shared problem perception, sustainability vision, agenda, experiments, instruments and monitoring through a process of social learning about radical systemic change offering sustainability benefits besides user benefits" [16] (p. 88). However, some critics argue that the approach of transition management lacks politics. The long-term changes brought about by the interactions between various uncertain factors such as future technological developments, interventions of many stakeholders and politicians, changes in markets, and consumers' lifestyles make the processes of transition more troublesome and contentious than transition management suggests [17]. Besides, it is a known fact that technological innovations and social system designs are not necessarily realized as they were planned to be [18-20].

An integrated governance scheme of various approaches mentioned above, which are not exhaustive, may be necessary to cope with complex governance problems. However, at the same time, an effort to integrate these different approaches may end up erecting an extremely complex theoretical framework that has no practical utility. Instead, this study takes the perspective of anticipatory governance to address complex governance problems such as energy transition and climate change. It is mainly because this perspective consists of a few key conceptual elements that prescribe how to manage complex governance problems and also provide us with the minimum yet substantive guidance to prepare for uncertain future events by the involvement of crucial stakeholders based on a normative decision and through reflexive processes. However, this approach does not seek the ultimate solution for governing the complex governance problems we face or providing a robust governance structure. Besides, this article is a case study at the initial stage of applying the concept of anticipatory governance to a social phenomenon to examine this concept's analytical usefulness.

\subsection{Anticipation and Anticipatory Governance}

The world and our lives are full of complexity, uncertainty, and unpredictability. Climate change, the COVID-19 pandemic, market volatility, and financial crises such as the Lehman shock of 2008 are recurrent, and the impacts of social network services (SNS) on the economy, society, and politics are unfathomable. However, if we are attentive to some warning signs to anticipate the worst possible consequence and prepare for it, we may substantially reduce the magnitude of the natural and human-made calamity [21] (p. 47). The devastation of Hurricane Katrina in 2005 and the Fukushima nuclear accident in 2011 are cases in point. Similarly, if we can collectively decide what kind of society we want to have [22] (pp. 118, 119), new technology, such as nanotechnology and artificial intelligence, can serve our needs well.

We assume that policymakers rely on science to make decisions by formulating alternative courses of action based on the rational calculation on costs and benefits. The current efforts to search for accurate information about climate change impacts on local areas through climate modellings based on computing power stem from the traditional approaches of optimum expected utility analysis to find validated and legitimated adaptation policies based on scientific knowledge. However, as Herbert Simon already pointed out, decision-makers are apt to be satisfied with a good enough decision when an optimal solution cannot be found $[23,24]$. This argument of bounded rationality is vital in dealing with a complex governance problem of climate change. It is because accurate climate predictions are limited by "fundamental, irreducible uncertainties" [25] (p. 67). The difficulties of 
climate prediction lie in limitations in knowledge such as cloud physics, the chaotic nature of the climate system, and human aspects of uncertainties about future greenhouse gas emissions, population, economic growth, development, globalization, cultural preferences and so on [25] (p. 67; p. 69).

Japan's Coordinating Committee for Earthquake Prediction (CCEP) (Jishin Yochi Renraku-kai), founded in April 1969, failed to predict the Great Hanshin-Awaji Earthquake of 17 January 1995 and the Great East Japan Earthquake and Tsunami on 11 March 2011. The critical common lessons from these great earthquakes are that effective responses to future earthquakes do not necessarily depend on prediction accuracy. It is good enough to have a general sense of where earthquakes occur and to anticipate and prepare for a range of plausible scenarios, if necessary, with computer simulations. As various experiences of earthquakes in the world inform us, "historical interpretation of earthquake occurrence, combined with present-day monitoring, has led to successful strategies for mitigating earthquake losses through appropriate engineering, land-use planning, and emergency management" [26] (p. 125). It is not to reject the use of science, which provides us with tremendous benefits brought by weather forecasts on hurricanes and the invention of vaccines. Still, policymakers' uncritical dependence on scientific prediction is not appropriate to deal with climate change and earthquakes.

When we think about systemic changes or systemic behaviors resulting from interactions of different levels of reality in "biological level (perception, brain processes), the psychological level (cognitive processes), and the social level (social interactions)" [27] (p. 13), the theory of causation loses its explanatory power. The theory of anticipation can fill the gap. According to Poli [27], there is not any integrated definition of anticipation yet. However, various disciplines have studied this concept over the past century. They include philosophy, physics, biology, brain studies, psychology, social sciences, semiotics, engineering, artificial intelligence, and future studies [28-33].

In the discipline of political science, the concept of anticipation was also used early on. Carl J. Friedrich employed the analytical concept of "anticipated reaction" to describe a power relationship between the parliament (or politicians) as a principal and bureaucrats as an agent. According to Friedrich, the parliament approves policy proposals of the bureaucracy in the latter's anticipated reaction in understanding what politicians want to do [34]. O'Neill quotes an insight of a contemporary constitutional scholar on the diffusion of political power to various actors: that is, "power can work through anticipation, so a power relationship may exist even absent visible compulsion" [35] (p. 293). More recently, Mansbridge [36] (pp. 515-528) includes anticipation as one of the four types of normative models on political representation. The traditional model of representation is a promissory representation that focused on the idea that representatives made promises to constituents during campaigns, which they then kept or failed to keep. The second model is an anticipatory representation that focuses on what representatives think their constituents will approve at the next election, not on what they promised to do at the last election.

The fields of future studies and governance quite extensively studied anticipation. Actions in the present are keys to ensuring the desired future to arrest terrorism, climate change, and trans-species epidemics such as avian flu and virus infections. As Anderson succinctly put it, the future is "constantly being folded into the here and now ... " [37] (p. 777). It is crucial to understand how anticipatory action works to realize how commonly the future is "present" in our daily lives [38]. Thinking about how to deal with not-yet-unfolded future disasters, we should at least be able to react appropriately to the advent of disaster, but it is quite essential to recognize that disaster is incubating within the present. We need to be attentive to the "early warnings" of danger, such as terrorism, climate change, and pandemics. Concerning anticipatory governance, Fuerth [39] (p. 29) succinctly maintains that anticipatory governance is "a system of institutions, rules, and norms that provide a way to use foresight to reduce risk, and to increase capacity to respond to events at early rather than later stages of their development."

Fuerth and Faber propose a workable strategy to cope with accelerating change and complex challenges that the U.S. government faces. Three critical elements for anticipatory governance are 
(1) foresight-policy integration, (2) networked governance, and (3) feedback for applied learning. According to Fuerth and Faber [21] (p. 42), the first element of anticipatory governance means that it "offers a system for integrating foresight into the way we create and execute national policies, including anticipation of upcoming challenges and opportunities as well as disciplined analysis of the long-range consequences of today's decisions." Considering the most effective and efficient governance, networked governance stresses the importance of "orchestrating whole-of-government management and budgeting to mission ... " The last critical element or feedback and applied learning is the process of reflection, which enables policymakers regularly to evaluate the "consequences against expectations as a way to learn from experience and refresh policy."

Similarly, concerning about the uncritical introduction of new technology, such as nanotechnology, into society and seeking to bend technoscience more toward humane ends, the Center for Nanotechnology in Society (CNS) at Arizona State University presents the center's vision of anticipatory governance. CNS's director David Guston defines it as "a broad-based capacity extended through a society that can act on a variety of inputs to manage emerging knowledge-based technologies while such management is still possible" [40] (p. 219). The three critical components of anticipatory governance are foresight, engagement, and integration. Each is defined as it follows [41]:

Foresight is a methodologically pluralist approach to plausible futures with an emphasis on such methods as scenario development that provide a more diverse and normative vision compared with other methods that seek to identify a single, most likely future.

Engagement refers directly to encouraging the substantive exchange of ideas among the lay public and between them and those who traditionally frame and set the agenda for and conduct scientific research.

Integration is the creation of opportunities, in both research and training, for substantive interchange across the "two cultures" divide that is aimed at the long-term reflective capacity building [40] (p. 226).

Although the definitions and the components of anticipatory governance mentioned above are to address the concerns about the utilization of new emerging technologies such as nanotechnology, geoengineering, and genetically modified organisms (GMOs), they share the common features of anticipatory governance in the fields of public policymaking about various issues including climate change, market volatility, and terrorism. For example, talking about governmental policymaking in general, Fuerth defines foresight as the capacity to anticipate alternative futures, based on sensitivity to weak signals, and an ability to visualize their consequences, in the form of multiple possible outcomes [39] (p. 16). The notion of "engagement" can be applied to "networked governance" between the policymaking circle and the general public, and the concept of "integration" used in the field of sociology of science resembles "feedback for applied learning" [21] (p. 42).

In short, as a working definition of anticipatory governance with three key components-foresight, engagement, and integration - the author refers to Guston's definition [40] (p. 226) mentioned above but expanding the scope of this definition beyond the relationships between scientists and engineers on the one hand and the lay public on the other. Thus, the author uses the terms engagement and integration interchangeably with those of networked governance and feedback for applied learning, respectively.

\subsection{Energy Transition to Mitigate Climate Change and Anticipatory Governance}

The energy transition to mitigate climate change is one of the prime examples of complex governance problems. It involves many different actors with different interests and goals, value pluralism, and contested prioritization of values on policy goals such as energy, security, and sustainability. Besides a range of uncertainties on empirical knowledge and technological developments, the lack of linear and unambiguous relationship between the production of knowledge and processes of policy decision-making and complexity breeds itself as a direct consequence of social reality [42]. Similarly, the energy transition appears to be one of wicked problems hard to pin down 
because the formulation of the problem is the problem [43]. They can be considered a symptom of another problem [37], and they are highly resistant to solutions [44].

According to Valkenburg and Cotella [42] (pp. 2,3), there are five crucial difficulties concerning energy transitions. The first is the differences in actors, interests, and interpretations of transition goals [42] (p. 2), [45]. Actors hold different positions depending on different socio-economic and technological systems. Secondly, the heterogeneity of relevant values is another difficulty in energy transitions [17]. Like Meadowcroft's argument, Shove and Walker [46] insist that energy transition governance studies lack the analysis of the politics of energy transitions. Different and contending values such as energy security versus sustainability lead to different policy actions, usually guided by dominant socio-economic and political forces or "hegemonic culture."

The third difficulty in energy transitions stems from uncertainties in knowledge and norm [45], [42] (p. 3). Knowledge about how energy systems function in connection to their socio-political context is mostly incomplete, and transitions are also uncertain affairs because they are future-oriented. Moreover, successful technologies in the future are unknown at present. These uncertainties relating to knowledge about energy systems raise normative questions. Since the future is unknown, we are not sure what we want for the future. We are also not sure about what kind of norms and values should be considered the most important in the future.

The fourth difficulty is the absence of a "linear and unambiguous relationship between the production of knowledge and processes of decision- and policymaking" [42] (p. 3). Policymaking processes involve not only expert knowledge but also power relations, including agenda-setting. Besides, reality always defies knowledge, and knowledge itself is constantly reframed when it circulates. Lastly, the difficulty relating to energy transitions is "a direct consequence of complex social reality: with every change in sociotechnical reality, new actors emerge, and others disappear from the stage" [42] (p. 3). Energy transitions pose various kinds of changes such as technological, socio-economic, and political changes while affecting people's lives. However, even the energy-transition scholars tend to regard people as consumers, mainly aggregate and undifferentiated human factors and the mere receivers of such changes, although they also interact with energy transitions. Valkenburg, Bijker, and Swierstra [47] (p. 3) argue that people's roles are crucial in the provision of local and practical knowledge and anticipatory perspective on a desirable way to organize society while anticipating the broader consequences of energy transitions.

Having identified significant uncertainties and difficulties associated with energy transitions, this study employs the fore-mentioned working definitions of anticipatory governance as the central analytical angles for the state of energy transitions to mitigate climate change in Japan. They are foresight, engagement, and integration/feedback for applied learning. As to foresight, Japanese long-term energy policy (details discussed later) will be assessed whether or not its approach is "a methodologically pluralist approach to plausible futures" with the consideration of "a more diverse and normative vision compared with other methods that seek to identify a single most likely future" [40] (p. 226). It is also examined that Japan's energy policy anticipates an alternative future "based on sensitivity to weak signals" and visualizes "their consequences, in the form of multiple possible outcomes" [39] (p. 16). Besides, unlike vision that tends to be a fixed image of the future, foresight is "based on assumptions that are always understood to be in flux and which are therefore treated as conditional" [39] (p. 17).

The second analytical angle of engagement most squarely addresses the questions of the politics of energy transitions to mitigate climate change in Japan. According to Guston [40] (p. 226), engagement refers to "encouraging the substantive exchange of ideas among the lay public and between them and those who traditionally frame and set agenda for, as well as to conduct, scientific research." In this study, the scope of the analytical object will be expanding beyond the issues revolving around new emerging technology by dealing with the energy and climate policy. Therefore, this study examines how extensively the substantive exchange of ideas and knowledge between energy policymaking circles and the lay public have been conducted. It also examines the agenda-setting processes and the implementation of actual policies. Furthermore, this study introduces two notions for the analysis of 
engagement following [42]. They are inclusiveness and closure, and the level of each notion determines how extensive the level of engagement among the lay public and between them and those who traditionally frame and set agenda on energy policy in Japan is.

According to Valkenburg and Cotella [42] (p. 6), the notion of closure is to "capture the extent to which modes of governance are socio-spatially distributed and mobilize agency of a broad variety of actors," and "the level of inclusiveness is low if only institutional and political actors matter and high if the general audience and market players etc. matter as well." The notion of closure is to capture "the extent to which propositions, in terms of their (re)definition and/or implementation, are open to negotiation or instead have closed down and become inevitable." Thus, when things are fixed, arrangements are institutionalized, and decisions become binding, the closure level is high. Contrarily, it is low if decisions are still being debated and contested [42] (p. 7). The scatter diagram of various governance modes, which are arranged according to the level of inclusion and closure/coercion, is reproduced below (Figure 1).

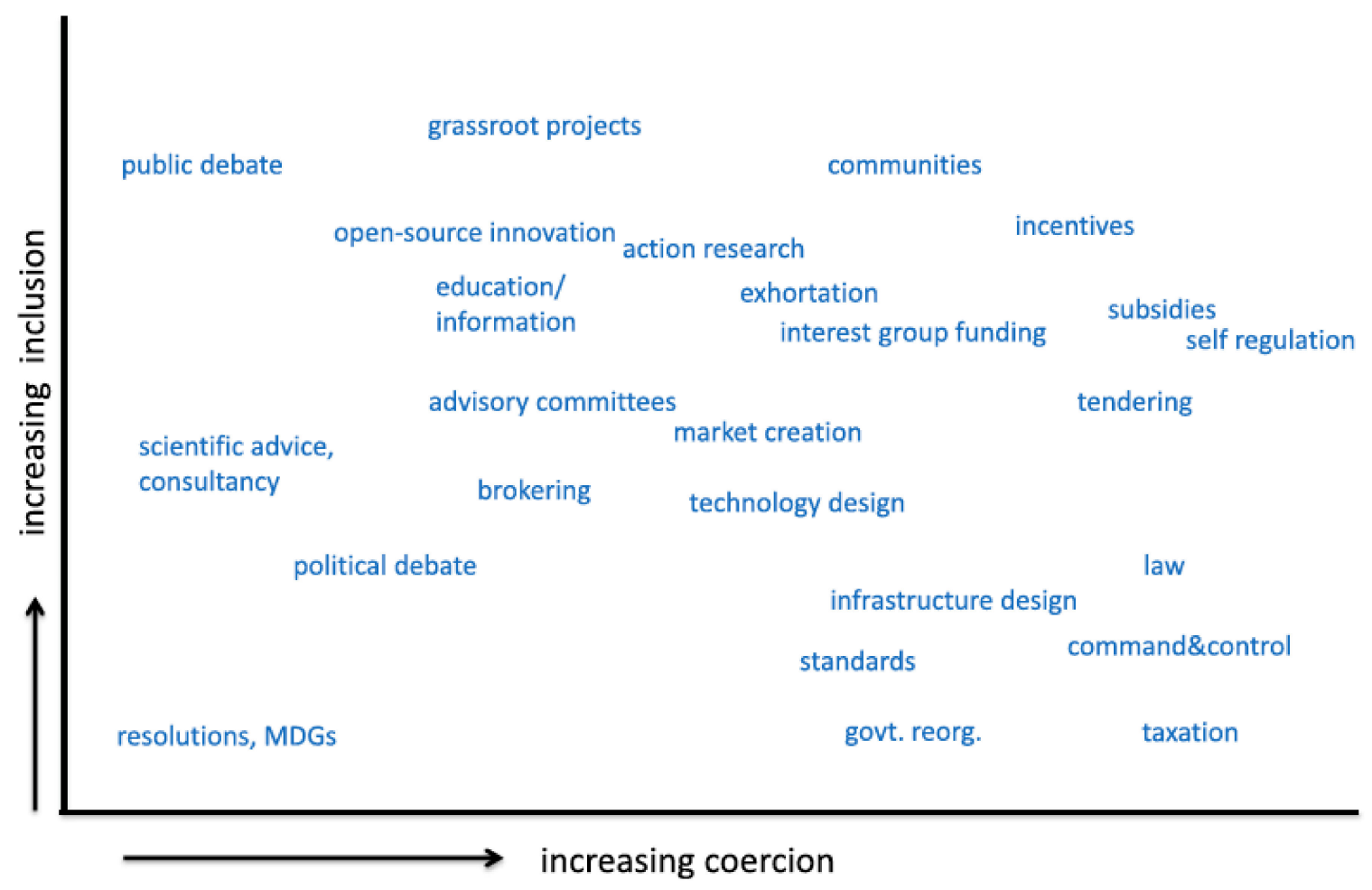

Figure 1. A two-dimensional classification of conventional modes of governance. Source: Valkenburg and Cotella [42] (p. 8).

Regarding integration/feedback for applied learning will examine whether or not Japanese energy-climate policymaking processes have a feedback system to "monitors and adjust policy relatively to initial expectations" and continue to assess "consequence against expectations as a way to learn from experience and refresh policy" [21] (p. 42). Energy transitions are complex and long-term processes, but they are also reflexive processes in which the present's decision will affect the future's policy options. Furthermore, we are uncertain about future technological developments, socio-economic, institutional arrangements, current lifestyles, and upheld values and norms in a society. Therefore, substantial interchanges between the "two cultures" [40] (p. 226) or between the lay public on the one hand and scientists and experts, as well as policymakers, on the other hand, are crucial to deciding collectively what the desired future is.

Now we take a closer look at Japan's energy and climate change policy through the lenses of anticipatory governance. 


\section{Japan's Energy Transitions to Mitigate Climate Change}

\subsection{The Institutionalization of Long-Term Energy Policy and "Foresight"}

The core concern of Japanese energy policy is security, especially after the first oil crisis of 1973. Since then, the government has considered nuclear energy the primary alternative source, not renewable energy sources, to reduce overseas oil dependency while promoting energy conservation. In February 1974, the Advisory Committee for Natural Resources and Energy was established under the auspices of the Ministry of International Trade and Industry (MITI) (since 2001, Ministry of Economy, Trade and Industry: METI) to adopt a long-term energy supply and demand policy every five years. Japan has maintained this alternative energy policy by funding exceptionally well through a complicated system of government subsidies based on the three laws for nuclear power development: namely, the Electric Power Development Taxation Law, the Special Budget Law for the Development of Electric Power, and the Law for the Adjustment for Areas Adjacent to Power Generating Facilities $[48,49]$. This so-called Dengen sampo (the three laws for power development) was introduced in June 1974. Since then, Japan had built 54 nuclear reactors with an installed capacity of about $45 \mathrm{GW}$, the third largest capacity in the world. According to a study [48] (pp. 30-50), since the 1970s, 70\% of the special power account whose source of revenue had been the electric power development tax and $97 \%$ of the energy expenditure in the national general account budget has been spent for the development of nuclear power.

Compared with its nuclear energy policy, Japan's renewable energy policy is meager. As to METI's policy relating to the latter, the New Energy Law of 1997 and the Special Measures Law on Promoting Use of New Energy by Electric Enterprises (RPS law) of 2003 are notable. The former law defines "new energy" (or renewables excluding hydro and geothermal energy sources) and encourages the measures to promote it. The RPS law required power utilities to generate a certain amount of electricity from new energy sources such as photovoltaic power, wind power, and biomass. However, this law did not encourage a full-scale introduction of "new energy" by subsidizing for maintaining a fixed price of electricity as Germany's similar policy does. Thus, the target 2010 under the RPS law aimed at generating only 12.2 billion $\mathrm{kWh}$ (excluding hydropower generation), or $1.2 \%$ of the electricity demand in 2006 [48] (p. 21).

In May 1980, after the second oil crisis, the Alternative Energy Law was enacted to develop and promote alternatives to oil. In December, the "Target for the Supply of Alternative Energies to Oil" was announced by the government. The criteria to select alternatives were twofold: they were already established as energy sources and expected to be supplied by a considerable amount in the future [50] (pp. 415-417), [51] (p. 290). According to these criteria, coal, nuclear, hydrogen, and geothermal were considered alternative energy sources to oil. In the electricity generation area, the Account for Diversification of Power Sources (Dengen tayouka kanjyou) allocated the budget for implementing the policy to seek alternatives to oil. The Account for Oil and Alternative Energy to Oil (Sekiyu oyobi sekiyudaitai enerugie kanjyou) financed the measures for seeking alternative sources.

Having the legal base and the allocation of the budgets for the promotion of alternative energy to oil, in 1980, the Agency for Natural Resources and Energy (ANRE) of the MITI set the target of the supply of alternative sources to oil toward 1990 or 10 years after the enactment of the 1980 Alternative Energy Law. The alternative energy mix in 1990 consisted of coal (35.4\%), nuclear $(21.8 \%)$, natural gas $(20.4 \%)$, hydro $(9.2 \%)$, geothermal $(2.1 \%)$, and others (solar thermal, coal gasification, etc.) [51] (p. 293). It can be argued that the root cause of Japan's underdevelopment of renewables and unambitious reduction targets of greenhouse gas emissions after the Fukushima nuclear accident lies in the ANRE's alternative energy options that considerably leaned to nuclear and coal [52] (pp. 206-265). The historical trend of Japan's primary energy supply from 1953 to 2018 (Figure 2 below) depicts the long-term energy policy's institutionalization. 


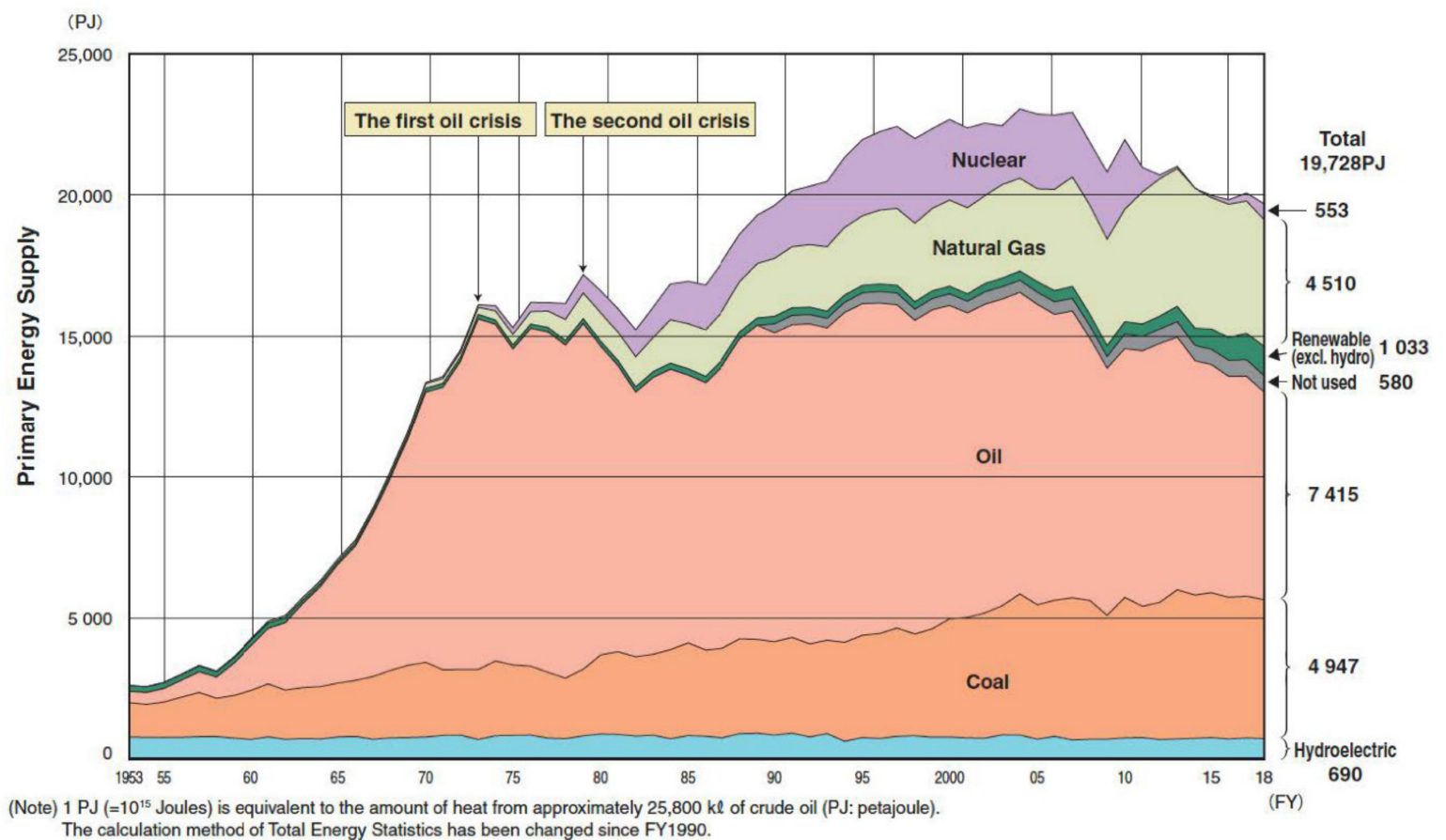

Figure 2. Historical trends in Japan's primary energy supply. Source: Agency for Natural Resources and Energy, Total Energy Statistics. Japan Atomic Energy Relations Organization (JAERO) [53].

From the aspect of anticipatory governance, Japan's long-term energy policy lacks foresight. It has not foreseen the possibilities of different energy sources and multiple future scenarios in long-term energy supply and demand, assuming unforeseen and drastic changes in industrial structures. Instead, it sticks to the initial policy of considering coal, nuclear, hydrogen, and geothermal energy as alternatives to oil, assuming the continuation of the same industrial structure. It also regards the same energy sources as the baseload energy for electricity generation (details will be mentioned later). Even when the construction of new nuclear power plants began stagnating in the mid-1990s, the energy agency promoted nuclear by insisting that it be clean without emitting carbon dioxide $\left(\mathrm{CO}_{2}\right)$.

However, nuclear power's contribution to reducing $\mathrm{CO}_{2}$ emissions is not substantial. It did help to curb the increase of $\mathrm{CO}_{2}$ emissions slightly, at best. Figure 3 from the National Greenhouse Gas Inventory Report of Japan (hereafter, the National Greenhouse Has (GHG) Inventory) shows the trends in greenhouse gas (GHG) emissions and reductions from 1990 to 2018 [54] (page 2-1). According to the National GHG Inventory [54] (page 2-2), the amount of $\mathrm{CO}_{2}$ emissions in 1990, the Kyoto Protocol's benchmark year, was 1158.4 million tones $(\mathrm{Mt})$, excluding sequestration (Land Use, Land-Use Change and Forestry: LULUCF). It was on overage 1208.6 Mt throughout the 1990s. In the 2000s, except 2009 $(1162.6 \mathrm{Mt})$, one year after the Lehman Financial Crisis of 2008, $\mathrm{CO}_{2}$ emissions excluding LULUCF were between 1231.9 and $1302.5 \mathrm{Mt}$. In sum, nuclear generation did not contribute to the substantial reduction of $\mathrm{CO}_{2}$ emissions throughout the observation period. 


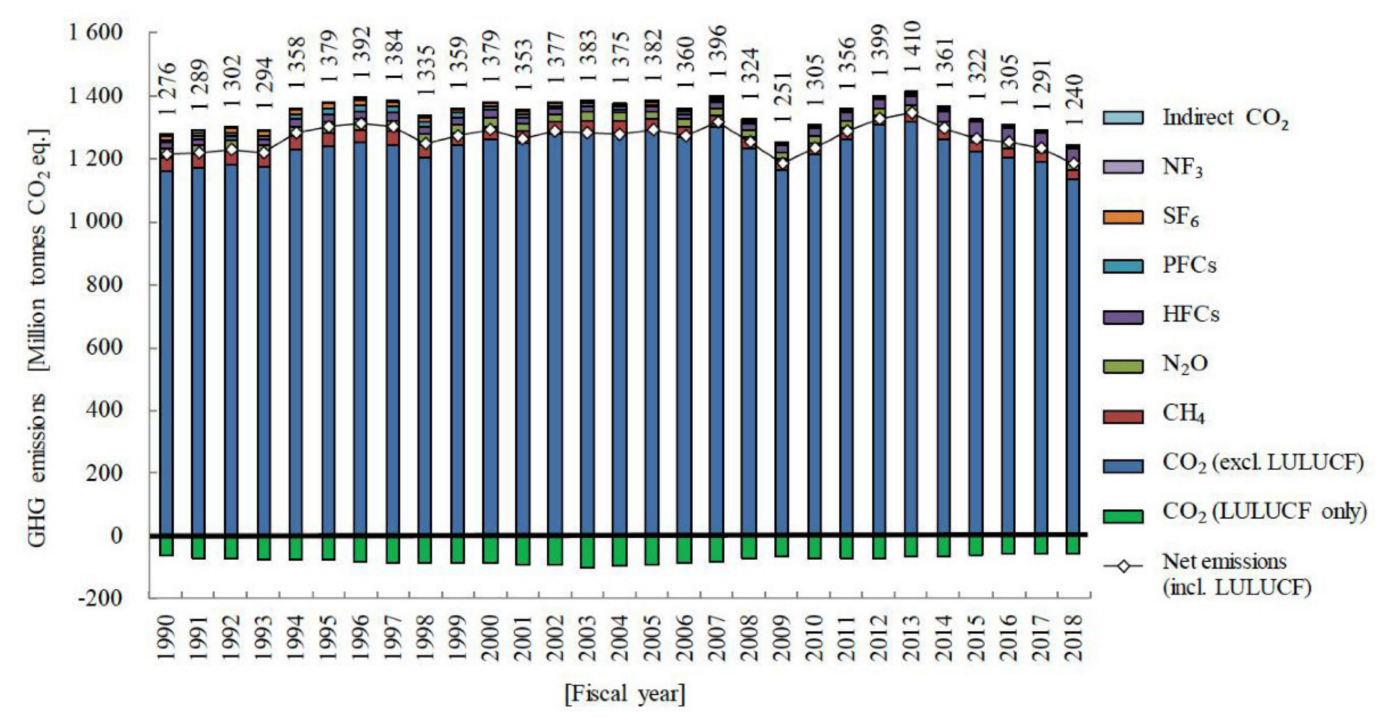

Figure 3. Trends in greenhouse gas (GHG) emissions and removals in Japan. Source: NIES: National Institute for Environmental Studies [54] (page 2-1).

The National GHG Inventory further reports that $\mathrm{CO}_{2}$ emissions from energy industries increased by $28.2 \%$ from the fiscal year (FY) 1990 to 2018 [54] (page 2-4). The $\mathrm{CO}_{2}$ emissions from "Public electricity and heat production" increased from 303,055 thousand tones in 1990 to 472, 488 thousand tones in 2018 (Table 1). Before the nuclear accident in March 2011, $\mathrm{CO}_{2}$ emissions gradually increased, and then after it, the emissions jumped because of the rapid increase of thermal power plants to cancel out the absence of nuclear generation. However, the governmental policy of promoting renewable energy one year after the nuclear disaster and the restart of several nuclear power plants contributed to the steady reduction of $\mathrm{CO}_{2}$ emissions. As will be discussed later, it is more likely that renewables can reduce $\mathrm{CO}_{2}$ emissions than nuclear can do.

Table 1. Trends in $\mathrm{CO}_{2}$ emissions in the energy sector (Thousand tones $\mathrm{CO}_{2}$ ).

\begin{tabular}{cccccccccc}
\hline Year & $\mathbf{1 9 9 0}$ & $\mathbf{1 9 9 5}$ & $\mathbf{2 0 0 0}$ & $\mathbf{2 0 0 5}$ & $\mathbf{2 0 1 0}$ & $\mathbf{2 0 1 1}$ & $\mathbf{2 0 1 2}$ & $\mathbf{2 0 1 5}$ & $\mathbf{2 0 1 8}$ \\
\hline Energy industries & 368,529 & 378,904 & 395,495 & 449,661 & 473,849 & 534,792 & 581,482 & 527,321 & 472,488 \\
\hline $\begin{array}{c}\text { Public electricity } \\
\text { and heat } \\
\text { production }\end{array}$ & 303,055 & 317,587 & 330,118 & 378,044 & 404,240 & 468,952 & 516,377 & 468,475 & 418,339 \\
\hline Petroleum refining & 36,397 & 41,085 & 46,978 & 50,888 & 47,715 & 44,478 & 43,298 & 41,664 & 36,211 \\
\hline $\begin{array}{c}\text { Manufacture of } \\
\text { solid fuels and } \\
\text { other energy } \\
\text { industries }\end{array}$ & 29,077 & 20,232 & 18,399 & 20,728 & 21,894 & 21,361 & 21,807 & 17,182 & 17,938 \\
\hline
\end{tabular}

Adapted from: The National GHG Inventory. NIES: National Institute for Environmental Studies [54] (page 2-5).

\subsection{Restricted Policy to Promote Renewables and "Engagement"}

Nevertheless, MITI encouraged the development of photovoltaic (PV) solar cell technology to develop an export industry to the extent that it did not undermine the status quo, especially the centralized power supply system, and the attending vested interests [3,4] (pp. 38-71). The following account on Japan's renewable energy policy is a partially reproduced and modified version of Ohta's previous work (forthcoming). As of 2005, Japan manufactured nearly 50\% of the world's photovoltaic (PV) solar cell products. It led the world in thin-film PV with the highest capacity of operational manufacturing plants. Kyocera, Kaneka, Matsushita Battery, Sanyo, Sharp, and Showa Shell Sekiyu had dominated the market. According to Kimura and Suzuki [55] (pp. 15, 16), five drivers promoted the development of photovoltaic solar cells. One of them was long-term R\&D or the 20-years of PV 
technological development under the Sunshine Project initiated by the New Energy Development Organization (NEDO), which was established after the second oil crisis of 1979. Although the NEDO first sought the technological development of the solar thermal power, its failure shifted to the development of PV in 1981 and lay the technological foundation for PV. The second driver was the PV industry's massive investment in this technology and their tenacity to persuade electricity power companies to allow reverse power flow from the household solar panel to power companies' transmission/distribution line [56] (p. 11). The third one was the efforts of the Office of Alternative Energy Policy of the MITI, which promoted solar energy and contributed to removing a barrier to generate electricity through a rooftop solar panel. MITI's regulation required an Electrical Chief Engineer for large-scale fossil-fuel power plants and the same regulation was initially to be applied to the household solar generation [55] (p. 11).

The fourth driver was the issue of climate change, which became an international political issue in the late 1980s, and the Japanese government agreed to pursue the stabilization of greenhouse gas emissions at the levels of 1990 by 2000. Kimura and Suzuki pointed out that climate change policy debates induced the electric power industry to accept the government's promotion of PV by starting a net-metering program in 1992 as a voluntary action. According to this program, electricity companies purchase electricity from residential PV systems at the price of 22 yen per $\mathrm{kW}$, the same fare as the residential electricity charge [55] (p. 13). The last driver was consumers' willingness to install rooftop solar panels knowing that they could not recover the initial cost even with governmental subsidy and sales of electricity through the net-metering program. As a result, since 1994, household rooftop installations of PV had rapidly increased. In 2006, with governmental subsidies, $94 \%$ of the PV installed in Japan was grid-connected residential PV systems [55] (p. 4).

The essential feature of Japan's energy policymaking is "closure" or the lack of engagement between the public and the experts. However, the case of the promotion of household rooftop PVs from the mid-1990s to the early-2000s is one of a few exceptions. The government decided to promote PV under uncertainties in future technological development and market growth. The important factors to encourage private firms' investment in this new technology were governmental initiatives in R\&D to develop new technology and set a long-term target of PV installations through the Sunshine program. These factors led to the creation of the market for PV technology despite a niche market. More importantly, the relatively small private companies fully committed themselves to the development of this technology and the creation of its market even going into deficits while tenaciously negotiating with giant power utilities to get access to their grids [56]. Furthermore, unexpected consumers' willingness to installing a rooftop PV without full recovery of the costs clearly shows that people as consumers are not merely aggregate and the undifferentiated human factor. Instead, it shows that they can play very active roles in the promotion of energy transitions and anticipatory perspective on what energy path society should take. They acted according to a normative reason for environmental concerns while knowing that the governmental subsidy and power company's electricity purchase could not recover the rooftop solar panel installation costs.

However, the Japanese government ended the policy of subsidy for PV in 2005. As a result, Japan, a one-time top-runner in solar energy use, lost the lead to Germany, which in February 2000 enacted the Renewable Energy Act (or Erneuerbare Energien Gesetz: EEG). This law's objective was to increase the volume of renewable energies in the power supply to $12.5 \%$ by 2010 , as one of the central elements of the German climate mitigation policy. The EEG's main feature was to oblige grid operators in Germany to purchase electricity generated by renewables at a fixed tariff. This feed-in-tariff (FIT) system aims to promote investment into renewable energy technologies and to ensure investment security. In contrast, the Japanese RPS law of 2003 did not seek a full-fledged development of renewables.

As to wind power generation, the Japanese market for wind power was negligible. Since 1990 the number of windmills had rapidly increased, and it reached 1050 in 2005 with the generation of more than $1000 \mathrm{MW}$. It appeared that this trend would continue to grow until the saturation of the wind power market. However, according to critics, there was no real "market" under the RPS law since 
$99.5 \%$ of the certificate "market" was covered by the ten regional electric power companies and the target for electricity generation by wind power (and other renewable resources) set under the RPS was also small [57]. Another impediment to the full-fledged growth of wind (and other renewable energy) market was a grid connection issue. Ten electric power companies regionally monopolized power lines so that other electric generators under the RPS law could not transmit electricity freely. Since power companies insisted that "stability of electricity supply" be their ultimate mission and "fluctuating" wind power be unreliable, they were unwilling to increase their purchase of electricity generated by wind power. As a result, the market for wind power never grew [57].

In sum, despite the plan for the expansion of new energy technology, the role assigned for renewables was minimal. They altogether occupied merely $3 \%$ of the total primary energy supply in the year 2010 [58]. This fact shows that the government did not intend to develop renewables as the primary energy source from the aspects of both energy security and climate change policy.

On the contrary, concerning nuclear energy METI's New National Energy Strategy of 2006 set up very high and ambitious targets for nuclear energy [59]. According to the 2006 Energy Strategy, the target of energy conservation was set at a 30\% improvement in energy efficiency by 2030. It called on the reduction of Japan's oil dependence to lower than $40 \%$ by 2030 . Meanwhile, it encouraged overseas resource development by Japanese developers to ensure $40 \%$ of total oil imports by 2030 . Nuclear power generation should increase at the level of 30\% to $40 \%$ or more by around 2030 [59]. Despite expanding new energy technology, the report failed to mention renewables as Japan's energy strategy components.

\subsection{The Window of Opportunity for Policy Innovation: "Engagement" and "Integration"}

The change of government from the LDP to the DPJ after the general election of 4 September 2009 brought an opportunity to overhaul Japan's energy and climate policy. At the UN Summit on Climate Change on 22 September 2009, Prime Minister Yukio Hatoyama pledged that Japan would reduce GHG emissions by $25 \%$ by 2020 from the 1990 levels if all major emitters also commit to ambitious reduction targets. Then, the Hatoyama cabinet approved on 12 March 2010 the Basic Global Warming Bill to fulfill the international pledge [60]. In order to achieve the mid-term target of reducing GHG emissions, the bill incorporated necessary policy proposals including the establishment of a domestic emissions trading system, the global warming tax, the introduction of the FIT system, the promotion of nuclear energy, the further improvement in energy efficiency, and the promotion of R\&D for innovative technologies. Although the Lower House passed this bill, the Upper House did not pass it during the ordinary Diet session in June 2010 due to the opposition parties' disapproval, and the government dropped this bill.

The Hatoyama government itself stumbled over the Futenma problem and the money scandals that struck him. Above all, it was detrimental that Hatoyama failed to fulfill the campaign promise of the relocation of U.S. Marine Corps Air Station Futenma outside the Okinawa Prefecture [61,62]. After the resignation of Hatoyama, Naoto Kan succeeded Hatoyama as prime minister on 8 June 2010. The Kan cabinet soon adopted the Basic Energy Plan. Accordingly, 70\% of sources of generating electricity would be non-fossil fuels or "zero emissions" by 2030, of which the share of renewables and nuclear would be $20 \%$ and $50 \%$, respectively. Towards this end, Japan had to build five new nuclear power plants by 2020 and another nine by $2030[63,64]$.

This energy strategy had to be fundamentally revised due to the Fukushima nuclear accident on 11 March 2011. A 9.0 magnitude earthquake struck off the coast of Sendai, Japan, and towering tsunamis swept away and destroyed essential facilities and equipment, including the emergency core cooling system (ECCS). The damage done by the earthquake and ensuing tsunamis forced Tokyo Electric Power Co. (TEPCO) to decide to decommission four nuclear reactors (from No. 1 to No. 4 reactor) of the Fukushima No. 1 nuclear power plant. In the wake of the accident and sensing a shift in public opinion on nuclear energy policy, Prime Minister Kan, (he was extremely unpopular since he advocated the increase of consumption tax by breaking the campaign pledge of no tax hike and 
a series of mismanagement relating to the Fukushima nuclear accident) who had barely avoided a non-confidence motion by his last-minute promise of resignation after a bill on renewable energy could pass the Diet. He pushed a bill to promote renewable energy through Diet. On 26 August 2011, the Special Measures Law on Procurement of Renewable Energy Sources Electricity by Electric Utilities was passed through Diet and went into effect on 1 July 2012. This law obliges the power companies to purchase at a fixed price the electricity generated by solar for 10 to 20 years, from geothermal for 15 years, and from wind, small-scale hydro, and biomass for 20 years.

Then, Yoshihiko Noda became prime minister on 30 August 2011. His political style and ideas resonated with the country's conventional prime minister of seeking a compromise within his party and between opposition parties [65]. The key policies that could tell Japan's future direction were how the newly enacted renewable energy law would be implemented and whether or not the governmental plan to limit reactors to 40 years of service could be maintained [66]. Noda faced severe criticism from both pro-nuclear interest groups and anti-nuclear groups. He maintained the "zero-nuclear reliance goal" policy of limiting reactors' operational life to 40 years despite heavy criticism by pro-nuclear interest groups. Pro-nuclear interest lobbies consisted of nuclear business/industry groups, Denryokusoren (the Federation of Electric Power Related Industry Worker's Unions of Japan), host local governments and international partners were concerned about its adverse impact on the economy. The Federation of Electric Power Company of Japan (FEPC) and nuclear industries are the core of nuclear-interest groups. Local governments that host nuclear power plants have also high economic stakes since they can receive subsidies and create jobs for nuclear facilities and their operation. The UK and France reprocess spent fuel produced at Japanese nuclear reactors so that they are concerned about Japan's nuclear policy change. However, despite Prime Minister Noda's declaration of attaining the state of a "cold shutdown" of nuclear reactors in the mid-December 2011, the accidents had not yet been entirely under control and more than 90,000 people at that time remained displaced away from the evacuation zone around the nuclear power plant [67]. The sense of distrust of nuclear safety has now spread among the Japanese along with the shared sense of "risk society" a la Ulrich Beck [68].

On 8 June 2012, Noda allowed restarting No. 3 and No. 4 of the Ōi nuclear power plant on the basis that the stable supply of electricity was imperative, and the authority established nuclear safety. Noda made this decision before the official report of the Fukushima Nuclear Accident Independent Investigation Commission of the National Diet of Japan was publicized [69]. Thus, it incited public opposition so much that a massive anti-nuclear rally was held on every Friday in front of the prime minister's office. Manabe scrutinized this phenomenon by arguing that music played a central role in expressing anti-nuclear sentiments and mobilizing political resistance in Japan [70]. At its peak, more than 200,000 people gathered together [71].

With the hope that the people could understand the necessity of nuclear energy use, on 29 June 2012, the Energy and Environment Council (EEC), which was established by the DPJ government in June 2011, announced the "Options for Energy and the Environment," based on the proposals from the Japan Atomic Energy Commission (JAEC), the Advisory Committee for Natural Resources and Energy (ACNRE) and the Central Environment Council (CEC). All these bodies are the Japanese governmental councils and commissions which were active in Tokyo, Japan. The EEC presented three scenarios to reduce nuclear dependence while achieving various policy objectives of ensuring nuclear safety, energy efficiency, cost reduction, as well as reducing $\mathrm{CO}_{2}$ emissions. Three nuclear options for 2030's energy mix and $\mathrm{CO}_{2}$ emissions reduction targets below the 1990 level include

1. zero nuclear energy option (65\% for thermal energy and $35 \%$ for natural renewable energy) and $23 \% \mathrm{CO}_{2}$ reduction,

2. $15 \%$ nuclear option (55\% thermal and $30 \%$ natural renewable) and $23 \% \mathrm{CO}_{2}$ reduction, and

3. $20-25 \%$ nuclear option (50\% for thermal and $25-30 \%$ for renewable) and $25 \% \mathrm{CO}_{2}$ reduction [72].

The government conducted a series of public opinion surveys consisted of the collection of public comments, public hearings, opinion polls, and deliberative polls from 2 July to 12 August in 
2012 [72]. During this period, the Noda government received 89,124 public comments and annotated 7000 comments, and about $90 \%$ endorsed zero nuclear option. Public hearings were held at 11 cities from 14 July and 4 August with 1447 people's participation in total, and 68\% of them supported the nuclear zero option. Eleven cities where public hearings were held include Fukushima, Sendai, Saitama, Osaka, Nagoya, Takamatsu, and Fukuoka. The deliberative poll included three separate surveys: a phone survey and questionnaire surveys before and after the debate forum. In the phone survey, $32.6 \%$ of the respondents supported the zero nuclear option, and two hundred 85 people attended a debate forum from the respondents of the phone survey who expressed the willingness to participate. In the questionnaire survey before the debate, $41 \%$ of the participants endorsed the zero option, but $46.7 \%$ of them supported the zero option after the debate [72]. This result was different from the government's preference of $15 \%$ nuclear option. After receiving information about nuclear power plants, listening to experts' opinions, and having a debate, more people became concerned about nuclear safety.

These processes of public hearings, public polls, deliberations were unusually open, participatory, "inclusive" in comparison with the conventional Japanese governmental policymaking process. It was a moment of the engagement between the public and policymakers, and, at the same time, they involved the process of integration in which they were about to make a normative decision about a future energy path.

The window of opportunity for policy innovation was shortly closed. At the general election on 16 December 2012, the LDP won the landslide victory and formed the coalition government with the Komeito. The LDP's electoral strategists were aware that the election was more a vote against the DPJ's mismanagement of economic affairs, security policies (the problems of the Senkaku/Diaoyu islands and the relocation of the Futenma US airbase) and the triple disasters of the earthquake, tsunami, and the nuclear accident than positive support of their party.

Contrary to Abe's forceful leadership in taking initiatives in security policy, energy policy, and climate change policy were lagging far behind. The mode of policymaking on energy and climate policy became similar to that of the pre-Fukushima era. Abe's LDP-Komeito coalition government adopted a new "Strategic Energy Plan" at the cabinet meeting on 11 April 2014. The new energy strategy ranked nuclear energy as vital baseload power. It allowed the restart of nuclear power plants without any conditions if the Nuclear Regulatory Authority (NRA) concluded that they have taken necessary measures to conform to the new safety regulations introduced after the Fukushima nuclear accident. The new energy strategy suggested the reversal of the previous administration's nuclear policy by suggesting the construction of new nuclear power plants. The DPJ's Innovative Strategy for Energy and the Environment (ISEE) had put forward a principle of a forty-year limitation of nuclear power plant operations and the policy that no construction of new nuclear power plants or no more installation of additional nuclear reactors would in the existing power plant. The new strategy also upheld the continuation of its nuclear fuel cycle policy by operating the trouble-plagued Monju, or the prototype fast-breeder reactor, (Monju was shut down in December 1995 following a sodium coolant leak and fire and subsequent cover-up attempt. It went online again in May 2010, but in August it was again forced to shut down because a fuel-loading device fell into the reactor vessel. It has been idle since then. Mizuho Aoki [73]), but the Abe government finally decided to decommission Monju on 21 December 2016. As to the target for renewable energy, while the DPJ government set up the concrete target of over 3000 billion kWh (3 times of the current level) by 2030, the LDP-Komeito government aims at about a $20 \%$ increase from the current level [74].

On 16 July 2015, the METI officially decided the power generation mix. It ranked nuclear energy as a stable and cost-effective source and allotted $20-22 \%$ for nuclear generation. The rate of increase for renewable energy was limited to 22-24 due to the relatively high cost of generation according to the METI [75]. METI's subcommittee of Long-term Energy Supply and Demand Outlook received 2060 public comments for about one month until 1 July. Contrary to the previous DPJ government's open and inclusive decision-making processes, the METI merely announced that opinions supported the 
scenario of zero nuclear or less than $10 \%$ nuclear and opposed the scenario of about $20 \%$ nuclear option. However, not only were the public comments not made available, but the METI did not disclose the rate of approval or disapproval for about $20 \%$ nuclear option and the power generation mix as a whole [76]. Facing the difficulties of building new nuclear reactors, the alternative for meeting the policy goal is extending the lifespan of existing reactors. However, it is even unknown how many existing power plants can restart. Therefore, it is unlikely to meet the governmental goal of $20 \%$ nuclear option due to the increasing costs of meeting tightened nuclear safety regulations.

Similar setbacks are discernable in the FIT policy concerning electricity deregulation. In September 2014, two years after implementing the FIT system, the Kyushu Electric Power stopped making new contracts to connect with its power grid the renewable electricity generated by private suppliers that were producing more than $10 \mathrm{~kW}$. The reason was the lack of the power grid capacity to receive electricity generated by renewable energies [77]. Since other electric powers had faced similar problems, the METI decided to provide subsidies to reinforce the power grid and improve large-sized storage batteries while also reviewing the FIT policy to correct the imbalance in different renewable energy sources. However, power generation by renewables remains low compared to many European countries whose annual power generation share of renewables exceeds 30\%. The ISEP estimated that the share of total renewable energy generation in Japan in 2018 had increased to $17.4 \%$ from $16.4 \%$ in the previous year. The share of solar PV power generation in Japan increased from $5.7 \%$ to $6.5 \%$ in 2018 . Wind power $(0.7 \%)$ and biomass $(2.2 \%)$ also tend to increase in power generation, but hydropower and geothermal power continue to remain the same amount. In passing, the share of fossil fuel-generated power was $78 \%$, and the nuclear was $4.7 \%$ in the same year [78]. The METI certainly needs to correct this imbalance in the supply of electricity generated by renewable sources. However, the fundamental problem is how electric power companies decide the volume of different sources of electricity that they allow to connect with the power grid or the allocation of "possible amounts of connection."

The METI prioritizes nuclear, thermal, hydro, and geothermal power generations as baseload electricity sources and first allocates "possible amounts of connection" with the power grid to these sources of electricity. Then, the remaining amounts are assigned to solar, wind, and biomass [79]. This policy generates two significant problems. The first problem is that it is against the FIT system's principle, which is supposed to prioritize the connection of electricity generated by renewables. The other problem is that the power company includes the "possible amounts of connection" with the nuclear power plants, which are to be restarted and still under construction. This kind of practice further reduces the allocation of renewable energy generation. On 13 October 2018, the Kyushu Electric Power, which faced the excessive generation of electricity, disconnected its power line from solar generators to keep operating four nuclear power plants [80]. One month later, Tohoku, Chugoku, and Okinawa Electric Powers announced they were also preparing to restrain renewable energy generation [81]. Okinawa Power Company does not have any nuclear power plants, but it operates under the rule of prioritizing the baseload electricity, which includes thermal power plants.

Moreover, there are two other factors for the promotion of renewable energy options: that is, electricity deregulation and the establishment of the system of separation of electrical power production from distribution and transmission. The liberalization of the Japanese electricity market began on 1 April 2016. As of 24 June 2020, according to METI, 658 retailers, including major municipal gas companies, have registered and are providing services [82]. However, an NGO, or the Power Shift (powershift.org), reports that there are only 28 entities (as of 13 June 2019), which can consider environmentally friendly. The criteria for the electricity label include: (1) the disclosure of information about energy mix and environmental loads for consumers to understand easily; (2) the main electricity supply comes from renewable energy power plants (including from the FIT); (3) no procurement from both nuclear and thermal power plants (except for 24-h backup electricity); (4) prioritize the supply from renewable power facilities of local communities and citizens; (5) no capital ties with a major power company (See http://power-shift.org/choice/). It is fair to say that the liberalization of the electricity market alone has not promoted enough renewable energy. It requires a more fundamental 
systemic change with proper procedures. A general procedure of electricity deregulation starts with the separation of transmission and distribution from a monopolistic electrical power. At the same time, the deregulation of the power generation sector itself takes place, and lastly, the deregulation of the retail sector comes [83] (p. 3).

In Japan's case, there are three phases of electric deregulation, and its order is not standard in comparison with other countries' approaches. The first step in Japan was to establish a regulatory organization: that is, the establishment of the Organization for Cross-regional Coordination Operation (OCCTO, established 1 April 2015), which "grasps and evaluates centrally the supply-demand balance nationwide and in supply areas for short-, mid-, and long-term" by aggregating all electricity companies' supply plans submitted to the METI [84]. This aggregate energy supply plan is, however, not a desirable approach from the foresight aspect since it relies on "a single most likely scenario" or the 10-year supply-demand forecast that does not necessarily reflect multiple, fluid, and uncertain future scenarios. The second step was the deregulation of the retail sector, which started on 1 April 2016. However, the final step or the separation of electrical power production from power distribution and transmission has just begun in 2020. It is desirable to establish a public or private entity to own and operate the transmission and distribution line independent of ten regional monopolies. Alternatively, at least, as EU countries do, while leaving the ownership rights of transmission lines to electric power companies, the operation of transmission lines should be independently managed by a public entity such as independent system operators (ISOs). However, the Japanese regulatory approach is to establish a "legally unbundling" transmission and distribution company that is still likely to maintain a financial relationship with parent power companies. Thus, it is yet to see how a transmission/distribution company provides fair access to new entrants independent of the electric power company's influence. It is crucial how closely the OCCTO along with the Electricity Market Surveillance Commission (EMSC), or another regulatory organization, can monitor fair access to power grids [83] (p. 4), [85] (pp. 28, 29).

\section{Discussion}

So, what about the politics of energy transitions in Japan [17]? One of the plausible explanations is the institutional inertia to cling to nuclear energy. To overcome the energy crises in the 1970s, the system consisted of legal, administrative, and private institutions were erected based on the Dengen sampo which helped create a vested interest of regional power companies, manufacturers, labor unions, host local cities, towns and villages, scientists, and concerned bureaucrats who had preyed on this system for a long time. This system was exclusive and called a "nuclear village" in a figurative sense. Here the theory of path dependence articulated by institutional historians can explain the genesis and the development of this system [86,87]. Besides, the long-term prospect of energy supply and demand, the policy of alternative energy to oil, and energy strategy of the ANRE reinforced the prioritization of "conventional energy sources" such as coal, natural gas and nuclear over "new energy" including solar and wind power. Critics see the supply-driven system managed by vertically integrated and centralized power companies, which control both electricity generation, and transmission and distribution, are the significant barrier to the development of renewables, which can generate electricity in a decentralized manner while being driven by local demand $[48,88]$.

How to promote and govern energy transitions in Japan is a challenging question to answer simply because even after the unprecedented nuclear accident, the current system stands firm to resist any substantial change in the energy policy. The Japanese energy agency and the industry still promote coal-fired power plants (CFPPs), and their investment in both upstream (coal mining) and downstream (CFPP development) continues, though scaling down $[89,90]$. Needless to say, the most advanced coal-fired power plant emits twice the amount of $\mathrm{CO}_{2}$ than an liquefied natural gas (LNG) plant does [91] (p. 27). The cost of electricity generation by a nuclear power plant in the world has been on the rise since 2012 while the costs of other energy sources are on the decline in which the costs of utility-scale PV (mega solar) and wind power has declined rather dramatically from 2009 to 2017, $-86 \%$ and $-68 \%$, respectively [91] (p. 28). However, the cost of generating electricity is merely a tiny 
aspect of complex nuclear problems that Japan faces today. They include the cost of compensation for the victims of the Fukushima nuclear accident, uncertainties regarding technical development and financial costs of taking out of spent fuels and decommissioning severely damaged nuclear reactors, finding ways and places to dispose of highly-irradiated nuclear wastes, and dealing with the excessive accumulation of plutonium, and more. Indeed, Japanese energy transitions need an anticipatory governance approach to address such complex governance problems adequately.

\section{Conclusions}

This is a preliminary and experimental study to analyze Japan's energy transitions to mitigate climate change from the aspects of anticipatory governance. One of the questions is to ask how anticipatory Japanese energy policy has been. This study assumes that no other country than Japan needs energy transitions from nuclear and fossil fuels to renewable energy, especially after the Fukushima nuclear accident, and the ensuing question is how Japan governs such transitions?

On the aspects of foresight, the author looked at the essential policies of the Agency for Natural Resources and Energy (ANRE) of MITI/METI. They include the long-term prospect of energy supply and demand, the initial policy of alternatives to oil, and the energy strategy. After the first oil crisis of 1973, the ANRE designated nuclear energy as one of the primary future alternatives to oil, and after the second oil crisis of 1979, both nuclear and coal received the lion's share of governmental financial supports, not renewables. Even after the Fukushima nuclear accident, nuclear is continuously considered one of the core sources, and the government assigns an ambitious target to nuclear in its energy mix for electricity generation without realistic and plausible plans. This study further needs a close content analysis of various mid- and long-term energy policies of Japan, but it points out that Japan's energy policy did not consider multiple futures. In other words, it lacks foresight even though the energy agency's policy has stressed its "ambitious multiple track scenario" and its policy tenets of 3E + S (Safety, Energy Security, Environment, and Energy Efficiency) [1]. The Fukushima nuclear accident revealed the inconsistency between ANRE's declared policy goals and the consequences of the persistent prioritization of nuclear over renewables. After Fukushima, most nuclear power plants have suspended operation for stringent safety inspections, whereas more thermal power plants have become operating, making Japan heavily dependent on imported natural gas and coals and emitting more $\mathrm{CO}_{2}$.

The essential feature of Japan's energy policymaking is "closure," which means its policymaking processes are not open to the public and excessively rely on experts and vested interest groups, lacking engagement or the interactions between the public and the experts. However, there are two exceptional cases: the development of PV solar panels and fairly inclusive policy discussions about future nuclear options after the Fukushima nuclear accident. In the former case, the NEDO, a quasi-governmental research institute, took initiatives in developing new solar panel technology and experimenting with it by sharing the information with private firms which, in turn, invested in new technological developments more than the government and made strenuous efforts to open the access to the grids of power utilities. Moreover, the government provided the consumers with the subsidy to install rooftop solar panels and made power companies start voluntary action such as the net-meter service. It is important to note that consumers are not merely faceless and aggregate human factors. Instead, they acted according to a normative reason for environmental concerns while knowing that the government subsidy and power company's electricity purchase could not recover the rooftop solar panel installation costs. The other case of extensive and lengthy policy dialogues was an unusually open, extensive, and time-consuming process to deliberate on Japan's future energy and environmental strategy among the lay public and between them and those who traditionally frame and set agenda for and execute policies. This engagement process was very "inclusive" contrary to conventional policymaking processes in Japan.

However, these two good examples of engagement suggest the lack of integration or feedback for applied learning in Japan's energy policymaking processes. Despite the opposition of the PV industry 
and the proponents of renewable energy, in 2005, the government stopped subsidizing for household installation of PV solar panels claiming that the initial policy objective of creating the self-sustaining growth of the PV industry was achieved [55] (p. 18). As a result, Japan, a one-time top-runner in solar energy use, lost the lead to Germany. There was no integration or feedback for applied learning from a successful case of PV solar power development to further integrate it into the core alternative energy policy with the broad participation of the society. There was a brief moment of opening the window of opportunity for policy innovation and integration, especially after the Fukushima nuclear accident. That window closed shortly though creating a nuclear regulatory agency independent of the industry and the METI and shaping a policy direction of the electricity liberalization.

The analysis of Japan's energy and climate policies through anticipatory governance sheds light on the importance of the following policymaking processes. Since energy transitions to mitigate climate change involve policy decisions under various uncertainties in socio-economic and technological developments, policymakers should be flexible and imaginative to draw multiple future scenarios, including preparing for the worst to reduce damages when it happens. Second, energy and climate policies need to consider the diverse interests and objectives of multi-stakeholders. Thus, the policymaking processes should be inclusive by promoting the engagement between the public and between policymakers and the public, aiming to arrive at a normative decision on what kind of future or society they collectively choose. Lastly, at the policy integration phase, policymakers should regularly evaluate the consequences of implemented policies to improve them continuously.

It may sound nothing novel. However, these policymaking processes are critical in Japan, which experienced the unprecedented nuclear accident, but still clings to nuclear energy and fossil fuels as the base road sources to generate electricity.

Funding: This work was supported by JSPS KAKENHI Grant Number 16KT0095 and JPJSBP120203502.

Acknowledgments: I want to thank Emily Boyd and Atsushi Ishii to understand better the concept of anticipatory governance. I also thank the colleagues, Koji Fukuda, Hidetoshi Nakamura, Paul Bacon, Motohiro Tsuchiya, Min Shu, Gregory Trencher (especially for energy transition), and three anonymous reviewers for helpful and constructive comments on earlier drafts of this paper.

Conflicts of Interest: The author declares no conflict of interest.

\section{References}

1. Minister of Economy, Industry and Trade (METI). Strategic Energy Plan. 2018. Available online: http: //www.enecho.meti.go.jp/en/category/others/basic_plan/5th/pdf/strategic_energy_plan.pdf (accessed on 26 August 2020).

2. Samuels, R.J. The Business of the Japanese State: Energy Markets in Comparative and Historical Perspective; Cornell University Press: Ithaca, NY, USA, 1987.

3. Moe, E. Vested Interests, Energy Efficiency and Renewables in Japan. Energy Policy 2012, 40, $260-273$. [CrossRef]

4. Moe, E. Renewable Energy Transformation or Fossil Fuel Backlash; Palgrave Macmillan: New York, NY, USA, 2015.

5. Kameyama, Y. Climate Change Policy in Japan: From the 1980s to 2015; Routledge: London, UK; New York, NY, USA, 2017.

6. Watanabe, R. Climate Policy Changes in Germany and Japan: A Path to Paradigmatic Policy Change; Routledge: London, UK; New York, NY, USA, 2011.

7. George, A.L.; Bennett, A. Case Studies and Theory Development in the Social Sciences; MIT Press: Cambridge, MA, USA, 2005.

8. Gray, B. Collaborating: Finding Common Ground for Multiparty Problems; Jossey-Bass: San Francisco, CA, USA, 1989.

9. Huxham, C. The challenge of collaborative governance. Public Manag. Int. J. Res. Theory 2000, 2, $337-357$. [CrossRef]

10. Klijn, E.H.; Koppenjan, J.F.M. Public Management and Policy Networks: Foundations of a network approach to governance. Public Manag. Int. J. Res. Theory 2000, 2, 135-158. [CrossRef] 
11. Van Bueren, E.M.; Klijn, E.H.; Koppenjan, J.F. Dealing with wicked problems in networks: Analyzing an environmental debate from a network perspective. J. Public Adm. Res. Theory 2003, 13, 193-212. [CrossRef]

12. Farrell, H.; Newman, A. The new politics of interdependence: Cross-national layering in trans-Atlantic regulatory disputes. Comp. Political Stud. 2015, 48, 497-526. [CrossRef]

13. Zürn, M. Global governance as multi-level governance. In Handbook on Multi-Level Governance; Henrik, E., Sonia, W., Michael, Z., Eds.; Edward Elgar: Northampton, UK, 2010; p. 81.

14. Folke, C.; Hahn, T.; Olsson, P.; Norberg, J. Adaptive governance of social-ecological systems. Annu. Rev. Environ. Resour. 2005, 30, 441-473. [CrossRef]

15. Geels, F.W.; Schot, J. Typology of sociotechnical transition pathways. Res. Policy 2007, 36, 399-417. [CrossRef]

16. Kemp, R.; Loorbach, D.; Rotmans, J. Transition management as a model for managing processes of co-evolution towards sustainable development. Int. J. Sustain. Dev. World Ecol. 2007, 14, 78-91. [CrossRef]

17. Meadowcroft, J. What about the politics? Sustainable development, transition management, and long term energy transitions. Policy Sci. 2009, 42, 323-340. [CrossRef]

18. Lindblom, C.E. The science of 'muddling through'. Public Adm. Rev. 1959, 19, 79-88. [CrossRef]

19. Cohen, M.D.; March, J.G.; Olsen, J.P. A Garbage Can Model of Organizational Choice. Adm. Sci. Q. 1972, 17, 1. [CrossRef]

20. Meadowcroft, J. Planning for sustainable development: What can be learned from the critics. In Planning for Sustainability; Kerry, M., Meadowcroft, J., Eds.; Routledge: London, UK, 1999; pp. 12-38.

21. Fuerth, L.S.; Faber, E.M.H. Anticipatory Governance: Winning the Future; The Futurist: Chicago, IL, USA, 2013; pp. $42-49$.

22. Toffler, A. Future Shock; Random House: New York, NY, USA, 1970.

23. Simon, H.A. Administrative Behavior: A Study of Decision-Making Processes in Administrative Organization; Macmillan: New York, NY, USA, 1947.

24. Simon, H.A. Rational choice and the structure of the environment. Psychol. Rev. 1956, 63, 129-138. [CrossRef] [PubMed]

25. Dessai, S.; Mike, H.; Robert, L.; Roger, P., Jr. Climate Prediction: A Limit to Adaptation? In Adapting to Climate Change: Thresholds, Values, Governance; Neil, A.W., Irene, L., O’Brien, K.L., Eds.; Cambridge University Press: Cambridge, UK, 2009; pp. 64-78.

26. Sarewitz, D.; Pielke, R. Prediction in science and policy. Technol. Soc. 1999, 21, 121-133. [CrossRef]

27. PPoli, R. The many aspects of anticipation. Foresight 2010, 12, 7-17. [CrossRef]

28. Husserl, E. On the Phenomenology of the Consciousness of Internal Time (1903-1917); Kluwer Academic: Dordrecht, The Netherlands, 1991.

29. Boyd, E.; Nykvist, B.; Borgström, S.; Stacewicz, I.A. Anticipatory governance for social-ecological resilience. Ambio 2015, 44, S149-S161. [CrossRef]

30. Dubois, D.M. Review of Incursive, Hyperincursive and Anticipatory Systems-Foundation of Anticipation in Electromagnetism. In Computing Anticipatory System; Dubois, D.M., Ed.; American Institute of Physics: College Park, MD, USA, 2000; pp. 3-30.

31. Rosen, R. Anticipatory Systems: Philosophical, Mathematical and Methodological Foundations; Pergamon Press: Oxford, UK, 1985.

32. Raby, C.R.; Alexis, D.M.; Dickinson, A.; Clayton, N.S. Planning for the future by western scrub-jays. Nature 2007, 445, 919-921. [CrossRef]

33. Stock, A.; Stock, C. A short history of ideo-motor action. Psychol. Res. 2004, 68, 176-188. [CrossRef]

34. Friedrich, C.J. Constitutional Government and Politics; Harper \& Brothers Publishers: New York, NY, USA, 1937.

35. O'Neill, J.; Carl, J. Friedrich's Legacy: Understanding Constitutionalism as a Political System. Eur. Leg. 2009, 14, 283-300. [CrossRef]

36. Mansbridge, J. Rethinking Representation. Am. Politi Sci. Rev. 2003, 97, 515-528. [CrossRef]

37. Anderson, B. Preemption, precaution, preparedness: Anticipatory action and future geographies. Prog. Hum. Geogr. 2010, 34, 777-798. [CrossRef]

38. Adams, B.; Chris, G. Future Matters: Action, Knowledge, Ethics; Brill: Leiden, The Netherlands, 2007.

39. Fuerth, L.S. Foresight and anticipatory governance. Foresight 2009, 11, 14-32. [CrossRef]

40. Guston, D.H. Understanding 'anticipatory governance'. Soc. Stud. Sci. 2014, 44, 218-242. [CrossRef] [PubMed] 
41. Barben, D.; Fisher, E.; Selin, C.; Guston, D.H. Anticipatory Governance of Nanotechnology: Foresight, Engagement, and Integration. In The Handbook of Science and Technology Studies, 3rd ed.; Edward, J.H., Olga, A., Eds.; The MIT Press: Cambridge, MA, USA, 2008; pp. 979-1000.

42. Valkenburg, G.; Cotella, G. Governance of energy transitions: About inclusion and closure in complex sociotechnical problems. Energy Sustain. Soc. 2016, 6, 739. [CrossRef]

43. Rittel, H.W.J.; Webber, M.M. Dilemmas in a general theory of planning. Policy Sci. 1973, 4, 155-169. [CrossRef]

44. Termeer, C.; Dewulf, A.; Breeman, G. Governance of Wicked Climate Adaptation Problems. In Innovative Approaches towards Low Carbon Economics; Springer: Berlin/Heidelberg, Germany, 2013; pp. 27-39.

45. Verbong, G.; Derk, L. Governing the Energy Transition: Reality, Illusion or Necessity? Routledge Studies in Sustainability Transitions; Routledge: London, UK; New York, NY, USA, 2012.

46. Shove, E.A.; Walker, G. Caution! Transitions Ahead: Politics, Practice, and Sustainable Transition Management. Environ. Plan. A Econ. Space 2007, 39, 763-770. [CrossRef]

47. Valkenburg, G.; Bijker, W.E.; Swierstra, T.E. Secure and Low-Carbon Energy Is Citizens' Energy: A Manifesto for Human-Based Governance of Secure and Low-Carbon Energy Transitions; The University of Maastricht: Maastricht, Netherlands, 2015.

48. Oshima, K.I. Saiseikanou Enerugii no Seijikeizaigaku: Enerugii Seisaku no Guriin Kaikaku ni Mukete (The Political Economy of Renewable Energy: Towards a Greening of Energy Policy); Toyo Keizai: Tokyo, Japan, 2010.

49. Yoshioka, H. Shinpan Genshiryoku-No Shakaishi: Sono Nihonteki Tenkai (The Social History of Nuclear Energy: Its Japonesque Development, New Edition); Asahi Shimbun Publications Inc.: Tokyo, Japan, 2011.

50. Kikkawa, T. Tsusansangyou Seisakushi 10: Shigen Enerugie Seisaku 1980-2000 (The History of Trade and Industry Policy 10: Natural Resources and Energy Policy 1980-2000); Keizaisangyou Chousakai: Tokyo, Japan, 2011.

51. Ministry of International Trade and Industry (Tsushou sangyou shou) (MITI). Tsushou Sangyou Shou Nenpou Showa55 Nenban (MITI Annual Report: The 1980 Fiscal Year); Tsushou Sangyou Shou Daijin Kanbou Chousatoukeibu (The Section of the Research and Statistics of the MITI Mister's Secretariat): Tokyo, Japan, 1980.

52. Ohta, H. Shuyoukoku no Kankyo to Enerugie-wo Meguru Hikakuseiji: Jizokukanou Shaka Heno Sentaku (Comparative Politics about the Environmental and Energy Policies of Major States: Make a Choice for A Sustainable Society); Toushindou: Tokyo, Japan, 2016.

53. Japan Atomic Energy Relations Organization (JAERO). Chapter 1 World Energy Situation and Japanese Energy Situation, The Collection of Graphs on Nuclear and Energies, an Energy Encyclopedia. Available online: https://www.ene100.jp/map_1_en (accessed on 14 September 2020).

54. Greenhouse Gas Inventory Office of Japan; Ministry of the Environment, Japan. National Greenhouse Gas Inventory Report of Japan. Center for Global Environmental Research; National Institute for Environmental Studies: Japan, 2020. Available online: http://www.nies.go.jp/gio/en/aboutghg/jqjm1000000kb5qe-att/NIRJPN-2020-v3.0_GIOweb.pdf (accessed on 26 August 2020).

55. Kimura, O.; Tatsujiro, S. 30 Years of Solar Energy Development in Japan: Co-evolution Process of Technology, Policies, and the Market. In Proceedings of the 2006 Berlin Conference on the Human Dimensions of Global Environmental Change: Resource Policies: Effectiveness Efficiency, and Equity, Berlin, Germany, 17-18 November 2006.

56. NEDO (New Energy and Industrial Technology Development). (Tokushu) Sanshain keikaku 40 shunen: Nihon no shinenerugi kaihatsu no gentenn, sono igi (A Special Issue 40th Anniversary of the Sunshine Project: Japan's Starting Point of the Development of New Technologies and Its Significance). Focus NEDO, September 2014; The Special Issue. Available online: https://www.nedo.go.jp/content/100574164.pdf (accessed on 1 October 2020).

57. Iida, T.; Kanie, N.; Maruyama, Y.; Nishikido, M.; Hondo, H. Renewable Energy and Social Innovation in Japan. Available online: http://www.isep.or.jp/images/press/060218swisspresen-1.pdf (accessed on 29 June 2020).

58. Yoneda, Y. The Spread of Solar Power Generation in Japan, JFS Newsletter (June) 2008, No.70, Japan for Sustainability. Available online: https://www.japanfs.org/en/news/archives/news_id027851.html (accessed on 29 June 2020).

59. Minister of Economy, Industry, and Trade (METI). New National Energy Strategy: Digest (May) 2006. Available online: http://warp.da.ndl.go.jp/info:ndljp/pid/11245844/www.enecho.meti.go.jp/en/reports/pdf/ newnationalenergystrategy2006.pdf (accessed on 29 June 2020). 
60. Minshuto; The Democratic Party of Japan (DPJ). The Basic Global Warming Bill. No. 19. In Proceedings of the 171st Diet Session, Tokyo, Japan, 24 April 2009.

61. Allen, D.; Chiyomi, S. Hatoyama: Moving Futenma Operations off Okinawa 'Not Possible', Stars and Stripes. 6 May 2010. Available online: https://www.stripes.com/news/hatoyama-moving-futenma-operations-offokinawa-not-possible-1.101805 (accessed on 29 June 2020).

62. Kyodo. Hatoyama Offers an Apology to Okinawa. The Japan Times, 24 May 2010. Available online: http://www. japantimes.co.jp/news/2010/05/24/national/hatoyama-offers-an-apology-to-okinawa/\#.WTtxQjNI2SM (accessed on 29 June 2020).

63. METI. Establishment of the Strategic Energy Plan of Japan. 2010. Available online: http://warp.da.ndl.go.jp/ info:ndljp/pid/3487098/www.meti.go.jp/english/press/data/20100618_08.html (accessed on 29 June 2020).

64. METI. The Strategic Energy Plan of Japan: Meeting Global Challenges and Securing Energy Futures (Summary) (Revised in June 2010). Available online: http://warp.da.ndl.go.jp/info:ndljp/pid/3487098/www. meti.go.jp/english/press/data/pdf/20100618_08a.pdf (accessed on 29 June 2020).

65. Fukue, N. Noda victorious in the race for prime minister: Fiscal hawk defeats Kaieda in a runoff for DPJ presidency. The Japan Times, 30 August 2011. Available online: https://www.japantimes.co.jp/news/2011/08/ 30/national/noda-victorious-in-race-for-prime-minister/ (accessed on 1 October 2020).

66. Kazuaki, N. Nuke regulators get teeth via bills. The Japan Times, 7 January 2012. Available online: https://www.japantimes.co.jp/news/2012/01/07/national/nuke-regulators-get-teeth-via-bills/(accessed on 1 October 2020).

67. Tabuchi, H. Japan's Prime Minister Declares Fukushima Plant Stable. The New York Times, 16 December 2011. Available online: https://www.nytimes.com/2011/12/17/world/asia/japans-prime-minister-declaresfukushima-plant-stable.html?auth=login-google1tap\&login=google1tap(accessed on 1 October 2020).

68. Beck, U. Risk Society: Towards New Modernity; Sage: London, UK, 1992.

69. National Diet of Japan Fukushima Nuclear Accident Independent Investigation Commission (NAIIC). The Official Report of the Fukushima Nuclear Accident Independent Investigation Commission, Executive Summary. 2012. Available online: http://warp.da.ndl.go.jp/info:ndljp/pid/3856371/naiic.go.jp/en/report/ (accessed on 29 June 2020).

70. Manabe, N. The Revolution Will Not Be Televised: Protest Music after Fukushima; Oxford University Press: Oxford, UK, 2015.

71. Anti-Nuclear Rally in Tokyo Marks 187th since the 2011 Disaster. Nuclear-News, 12 March 2016. Available online: https:/nuclear-news.net/2016/03/12/protesters-rally-in-front-of-pm-office-diet-calling-forend-to-nuclear-power/(accessed on 1 October 2020).

72. Enerugi-Kankyo Kaigi (Energy and Environment Council). Enerugi-Kankyo ni Kansuru Sentaku (Choice about Energy and Environment). 29 June 2012. Available online: http://www.env.go.jp/council/ 06earth/y060-110/mat01_2.pdf (accessed on 29 June 2020).

73. Aoki, M. Fate of troubled Monju reactor hangs in the balance. The Japan Times, 23 November 2015. Available online: http://www.japantimes.co.jp/news/2015/11/23/reference/fate-of-troubled-monju-reactorhangs-in-the-balance/\#.VxNQqmO7dJM(accessed on 29 June 2020).

74. METI. Strategic Energy Plan, April 2014. Available online: http://www.enecho.meti.go.jp/en/category/others/ basic_plan/pdf/4th_strategic_energy_plan.pdf (accessed on 29 June 2020).

75. METI. Long-Term Energy Supply and Demand Outlook, (July) 2015. Available online: http://www.meti.go. jp/english/press/2015/0716_01.html (accessed on 30 June 2020).

76. Asahi Shimbun. 'Genpatsu niwari' pabukome: Sudo'ori, shosai/sanpi shimesazu: 2030 nen dengenkosei kettei ('Nulcer 20\%' The total of 2000 public comments were ignored. No details nor (the rate of) the pros and cons were revealed: The energy mix of 2030 was decided). Asahi Shimbun, 17 July 2015; 7.

77. Asahi Shimbun. Sai-ene horyu kennai 13,000 ken, Gyosha/Ken dokou chushi, Oita Prefecture (Suspend buying 13,000 renewables within the prefecture; Traders/the prefectural government watch the development closely/ Oita Prefecture). Asahi Shimbun, 25 September 2014; 33.

78. ISEP (Kankyo Enerrugi Kenkyujyo (Institute for Sustainable Energy Policies)). Share of Renewable Energy Power in Japan, 2018 (Preliminary Report). Available online: https://www.isep.or.jp/en/717/ (accessed on 30 June 2020). 
79. Asahin Shimbun. Koteikaitori yokuseini ironmo, Saiene pubukome 3000 ken, Shinru-ru ichibu miokuri (There are objections to restrain feed-in-tariff, renewables, and 3000 public comments; some new rules are put off). Asahi Shimbun, 17 January 2015; 5.

80. Asahin Shimbun. Kyuden taiyoko-wo yokusei jukyuchousei, genpatsu-ha tsujyou unten (The Kushu Power Company restrains solar and adjusts the supply-demand balance; Nuclear plants are in regular operation). Asahi Shimbun, 14 October 2018; 1.

81. Asahin Shimbun. Sai-ene shutsuryoku yokusei, Kyushu-igaidemo junbi, Tohoku, Chugoku-de (Beside the Kyushu Electric Power, the Tohoku and the Chugoku prepare for restraining renewables' generation). Asahi Shimbun, 13 November 2018; 9.

82. The Agency of Natural Resources and Energy (ANRE). Available online: http://www.enecho.meti.go.jp/ category/electricity_and_gas/electric/summary/retailers_list/ (accessed on 30 June 2020).

83. Ito, K. Deregulation of Japan's Electricity Market: Key Factors Needed for Success, Energy Policy Institute at the University of Chicago (EPIC) (1 March) 2016. Available online: https://epic.uchicago.edu/newsevents/news/deregulation-japan \%E2\%80\%99s-electricity-market-key-factors-needed-success (accessed on 30 June 2020).

84. OCCTO. Secure Short-Term to Mid- to Long-Term Stable Supply. Available online: https://www.occto.or.jp/ en/about_occto/securing.html (accessed on 25 August 2020).

85. SEP. Shizen Enerugi Hakusho 2014 (The Whitepaper of Natural Energy 2014). 2014. Available online: http://www.isep.or.jp/jsr2014 (accessed on 30 June 2020).

86. Pierson, P. Politics in Time: History, Institutions, and Social Analysis; Princeton University Press: Princeton, NJ, USA, 2004.

87. Hacker, J.S. The Historical Logic of National Health Insurance: Structure and Sequence in the Development of British, Canadian, and U.S. Medical Policy. Stud. Am. Politi-Dev. 1998, 12, 57-130. [CrossRef]

88. Iida, T. Enerugie Shinkaron: "Daiyon no Kakumei" ga Nihon-wo Kaeru (The Theory of Energy Evolution: "The Fourth Revolution" Changes Japan); Chikuma Shobo: Tokyo, Japan, 2011.

89. Trencher, G.; Healy, N.; Hasegawa, K.; Asuka, J. Discursive resistance to phasing out coal-fired electricity: Narratives in Japan's coal regime. Energy Policy 2019, 132, 782-796. [CrossRef]

90. Trencher, G.; Downie, C.; Hasegawa, K.; Asuka, J. Divestment trends in Japan's international coal businesses. Renew. Sustain. Energy Rev. 2020, 124, 109779. [CrossRef]

91. Ministry of Foreign Affairs of Japan (MOFA). Advisory Panel to the Foreign Minister on Climate Change, Recommendations on Energy Promote New Diplomacy on Energy through Leading Global Efforts against Climate Change. February 2018; SLIDE DECK. 